\title{
The bedrock geology under the Inland Ice: the next major challenge for Greenland mapping
}

\author{
Peter R. Dawes
}

Geological maps are of vital importance for documenting and advancing geological knowledge and they are a prerequisite for any meaningful evaluation of economic resources. In Greenland, mapping is taking place on the mainland - that for two centuries has been the traditional exploration target - and offshore, where only in the last decades has hydrocarbon exploration moved to the continental shelves.

Greenland with its $2166000 \mathrm{~km}^{2}$ is the largest island in the world. However, the land is overwhelmed by ice. A central ice sheet - the Inland Ice - blankets some $81 \%$ of the country reducing rock outcrop to a coastal fringe 0 to 300 $\mathrm{km}$ wide (Fig. 1). The continental shelves comprise a little more than twice the area of this fringe, $c .830000 \mathrm{~km}^{2}$.

This preamble serves to emphasise that Greenland's three physiographic units - exposed fringe, offshore and Inland Ice - are of very different size and that mapping has focused on the smallest acreage. Piecing together the composition of the largest, and hitherto unexplored, unit constitutes the next chapter of Greenland mapping.

\section{Historical perspective and aim of this paper}

In the last 25 years, great strides have been made in geological understanding as can be seen from two 1:2 500000 maps (Escher 1970; Escher \& Pulvertaft 1995). Apart from the progress recorded in the ice-free fringe, the 1995 map provides a first interpretation of the offshore, and it also includes information of sub-ice bedrock although this is but a single blob of colour at borehole GISP 2 (Fig. 1).

This paper's aim is to provide a first graphic interpretation of the bedrock under the Inland Ice and to review data sources. Its four-page limit does not allow citation of specific sources; these will be covered in a forthcoming paper. This state-of-the-art map is naturally rudimentary in approach with all boundaries arbitrary but it has the prospect of directing attention to future data assembly.

\section{The state of knowledge 2008}

Present knowledge of sub-ice geology is based on six main sources, each discussed below with emphasis on its use in compilation of the geological map shown in Fig. 1.

\section{Drill sites}

Drilling through the ice is the ultimate way of determining substratum composition. However, the only in situ rock sampled is from borehole GISP 2 - an Archaean granitoid rock reactivated during the Palaeoproterozoic (Fig. 1). Other ice cores have revealed information about rock debris, for example, Camp Century (Fountain et al. 1981).

\section{Nunataks}

Nunataks are restricted to the Inland Ice margin within $c .30$ $\mathrm{km}$ of the nearest land. Most expose locally known rocks and are important for piecing together structural make-up. Of importance for the new map is the $120 \mathrm{~km}$ long N-S string of nunataks west of Dronning Louise Land, North-East Greenland. They infer larger sub-ice occurrences of Mesoproterozoic sediments than exist on the neighbouring land.

\section{Coast to coast correlation}

Greenland's tapering form enables Precambrian rocks to be correlated across its southern tip and, by extrapolation farther north, under the ice. The presence on both coasts of Archaean rocks flanked north and south by Palaeoproterozoic orogenic belts allows the sub-ice projection of the North Atlantic craton although its southern and northern boundaries are hidden for $250 \mathrm{~km}$ and $500 \mathrm{~km}$, respectively. This correlation is strengthened by aeromagnetic data (Fig. 2).

The disappearance of Palaeogene extrusives on both sides of the Inland Ice might suggest a single province. However, both coasts are eruption sites connected to continental breakup but since the role of plumes and hot-spots is still unclear, basalts cannot be excluded from central Greenland.

\section{Glacial erratics}

The Inland Ice is a relic of a vast Pleistocene ice cover and the surrounding land is strewn with rocks dropped as the ice retreated. Broadly speaking, erratic suites from southern Greenland represent extensively exposed Precambrian and late Phanerozoic provinces whereas farther north, exotic Precambrian-Palaeozoic suites relate to sub-ice occurrences that are unknown or not exposed locally. Moreover, even the 


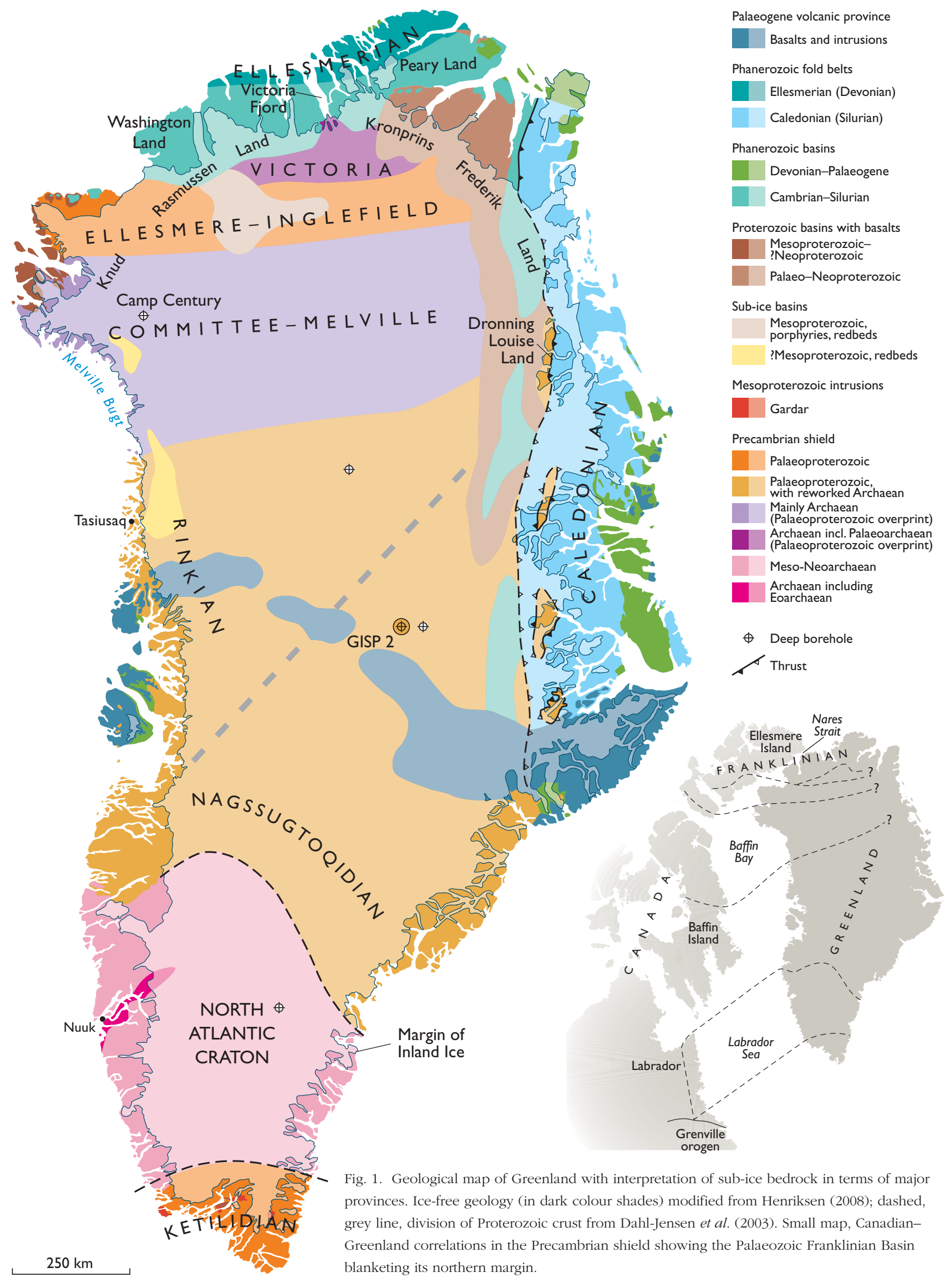




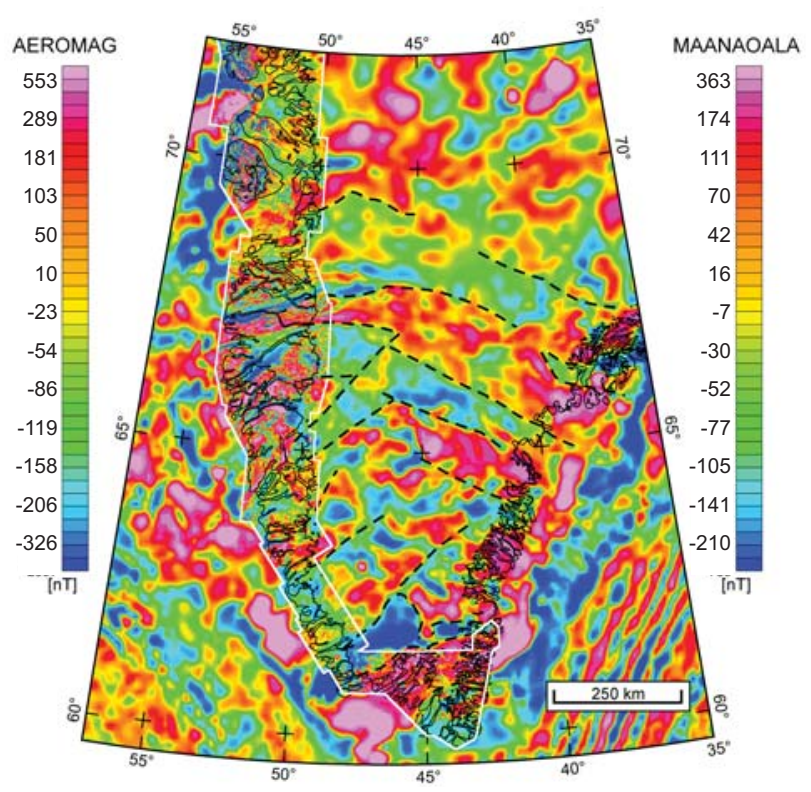

Fig. 2. Grids of total magnetic field over southern Greenland and offshore based on Verhoef et al. (1996, low resolution MAANAOALA data, Geological Survey of Canada) and white frame, high resolution AEROMAG data (Geological Survey of Denmark and Greenland). Stippled lines, geological trends by B.M. Stensgaard (personal communication 2009).

absence of particular erratics can be informative, for example, this author has no knowledge of erratics that might indicate a late Palaeozoic - Mesozoic sub-ice source.

Information from five erratic suites is incorporated into Fig. 1. Glacial drift across the Proterozoic-Phanerozoic platform of North Greenland is characterised by shield blocks granitoid rocks, gneisses and associated rocks. Most of these need laboratory work to cast light on their age and use in reflecting hidden provinces (see 1 below) but some rocks are ready-made indicators $(2,3)$. Farther south, exotic suites occur on the shield terrain of the west and east coasts $(4,5)$.

1. The shield erratics isotopically dated are from Peary Land and environs and they suggest sub-ice Archaean crust affected by strong Palaeoproterozoic overprint.

2. Banded iron formation (BIF) characterises the Neoarchaean Committee-Melville orogen of Baffin Island and North-West Greenland. BIF erratics in North Greenland suggest an extension of this terrane far to the east.

3. Erratics of porphyries and basalt, with rare sandstone, in Washington Land indicate a sub-ice volcanic-redbed province (Fig. 3A). Preliminary isotopic work points to a Mesoproterozoic age.

4. Red sandstone and siltstone erratics around Tasiusaq and farther north in North-West Greenland point to extensive sub-ice sources (Fig. 3B).

5. Erratics along the East Greenland ice margin were emphasised by Haller (1971, fig. 48): Proterozoic sandstone and basalt, Cambrian quartzite with Skolithos and Ordovician limestone infer extensive sub-ice sources.

\section{Detrital provenance studies}

Age and palaeoflow history of detritus within sedimentary rocks - rock clasts and crystals - can be relevant for sub-ice geology. However, minerals like zircon can be transported thousands of kilometres before deposition and identifying sub-ice geology on grains alone is problematical. Thus, the clast-grain couplet of the tilloidal Neoproterozoic Morænesø Formation in southern Peary Land is relevant, particularly so with its south-westerly provenance (Kirkland et al. 2009).

Clasts are of local Mesoproterozoic sandstone and dolerite, with less frequent granitoid rocks, BIF and porphyry, suggesting proximal sub-ice sources of Neoarchaean and Mesoproterozoic ages. Age estimates of zircons from granitoid clasts are $2.7 \mathrm{Ga}$ with overprinting at $1.25 \mathrm{Ga}$. Zircon crystals range from Palaeoarchaean to Mesoproterozoic with strong Palaeoproterozoic peaks suggesting large sub-ice areas. A minor $3.3 \mathrm{Ga}$ peak is an obvious link to the substratum (Victoria Fjord complex) that contains the only known rocks of this age in Greenland (Nutman et al. 2008). Moreover, the subsidiary status of these grains compared to Neoarchaean also exists in sequential Mesoproterozoic and Cambrian strata implying that Palaeoarchaean rocks form but a minor component of the complex. Kirkland et al. (2009) favour two south-western sources for Mesoproterozic detritus: proximal sub-ice Grenville-overprinted rocks and the type Grenvillian of Labrador, more than $2000 \mathrm{~km}$ distant. A third source is suggested by Fig. 1: the sub-ice volcanic province that may also source the rare porphyry clasts.

\section{Geophysics}

Geophysical methods - satellite, airborne or ice based undoubtedly have great potential for mapping the sub-ice geology. Preliminary interpretations about structure and
A

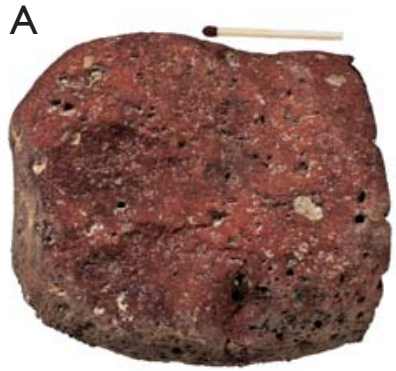

B

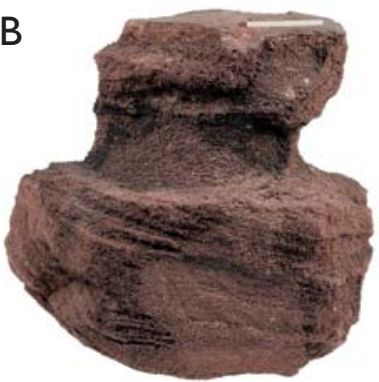

Fig. 3. Glacial erratics from sub-ice provinces unknown in outcrop. A Feldspar porphyry from Washington Land, western North Greenland, GGU 425204. Other porphyry erratics are illustrated in Dawes et al. 2000, fig. 3. B: Coarse-grained, cross-bedded sandstone from Tasiusaq area, North-West Greenland, GGU 457508. Photos: Jakob Lautrup. 
crustal thickness can be made from regional magnetic and gravity surveys. The power of aeromagnetics is illustrated by Verhoef et al.'s (1996) compilation of reconnaissance data that shows arcuate coast to coast anomalies coinciding with tectonic segments of the Nagssugtoqidian orogen, while mergence with high-resolution coastal data allows some structural subdivision of the shield (Fig. 2).

Radar and remote-sensing techniques provide physiographic details about the sub-ice landscape, for example, Legarsky et al.'s (1998) work used to locate the volcanic province in Knud Rasmussen Land (Fig. 1). Many tectonic provinces display distinct physiographical characteristics and thus 3-D imagery is vital for mapping sub-ice geology. Mountains, plains, plateaux and lowlands are not the only geological indicators, but hills and valleys affect ice dynamics and control water flow, two primary parameters for determining provenances of erratics and detrital material.

\section{Conclusions, future research, ice recession and economic potential}

A main conclusion must be that while mapping below the ice is in its infancy, the status of the GEUS databases has promising potential for planning research, whether sampling, drilling or geophysics. One dire need is for low-altitude and ice-based geophysical surveys to facilitate deductions about spatial relationships of sub-ice provinces. The new map leads to eight conclusions, but being conjectural, it raises important questions - too many to discuss in this short paper.

1. Provinces unknown in outcrop occur below the ice.

2. Where it is widest, in the north, the Inland Ice hides the most variable geology: Palaeoarchaean, Neoarchaean, Palaeoproterozoic, Mesoproterozoic and Palaeozoic provinces.

3. Archaean crust underlies Kronprins Frederik Land but its eastern connection is unknown.

4. Whether the Ellesmere-Inglefield juvenile crust links genetically and structurally (or at all) with Palaeoproterozoic rocks within the Caledonian fold belt remains open.

5. The volcanic province of Knud Rasmussen Land reinforces the profusion of Proterozoic rift-related magmatism along the rim of the North American craton.

6. Mesoproterozoic-Ordovician rocks are widespread beyond the Caledonian front linking northern foreland outcrops to sub-ice occurrences in central East Greenland.

7. The potential for sub-ice basins of late Palaeozoic Mesozoic age is limited.
8. The presence of Palaeogene volcanic rocks in central Greenland cannot be dismissed.

Currently, Greenland plays centre stage in the global climate debate, its recessive ice margin with spectacular, shrinking glaciers being international attractions. With this coveted popularity come startling prophecies, for example, "as its huge ice sheets begin to melt, it [Greenland] could find itself sitting on a fortune in oil and gems" (Barkham 2008). Be this as it may, before the rocks of the hidden $81 \%$ have been mapped, assessments of economic potential - often judged poor compared with neighbouring Canada despite common geology (Fig. 1) - remains equivocal.

\section{References}

Barkham, P. 2008: Beyond the ice. The Guardian, 11 December 2008, electronic version. London: Guardian News \& Media.

Dahl-Jensen, T., Larsen, T.B., Woelbern, I., Bach, T., Hanka, W., Kind, R., Gregersen, S., Mosegaard, K., Voss, P. \& Gudmundsson, O. 2003: Depth to Moho in Greenland: receiver-function analysis suggests two Proterozoic blocks in Greenland. Earth and Planetary Science Letters 205, 379-393.

Dawes, P.R., Thomassen, B. \& Andersson, T.I. 2000: A new volcanic province: evidence from glacial erratics in western North Greenland. Geology of Greenland Survey Bulletin 186, 35-41.

Escher, A. 1970: Geological/tectonic map of Greenland, 1:2 500000. Copenhagen: Geological Survey of Greenland.

Escher, J.C. \& Pulvertaft, T.C.R. 1995: Geological map of Greenland, 1:2 500 000. Copenhagen: Geological Survey of Greenland.

Fountain, J., Usselman, T.M., Wooden, J. \& Langway, C.C. 1981: Evidence of the bedrock beneath the Greenland ice sheet, near Camp Century, Greenland. Journal of Glaciology 27(95), 193-197.

Haller, J. 1971: Geology of the East Greenland Caledonides, 413 pp. New York: Interscience Publishers.

Henriksen, N. 2008: Geological history of Greenland, 272 pp. Copenhagen: Geological Survey of Denmark and Greenland.

Kirkland, C.L., Pease, V., Whitehouse, M.J. \& Ineson, J.R. 2009: Provenance record from Mesoproterozoic-Cambrian sediments of Peary Land, North Greenland; implications for the ice-covered shield and Laurentian palaeogeography. Precambrian Research 170, 43-60.

Legarsky, J., Wong, A., Akins, T. \& Gogineni, S.P. 1998: Detection of hills from radar in central-northern Greenland. Journal of Glaciology 44(146), 182-184.

Nutman, A.P., Dawes, P.R., Kalsbeek, F. \& Hamilton, M.A. 2008: Palaeoproterozoic and Archaean gneiss complexes in northern Greenland: Palaeoproterozoic terrane assembly in the High Arctic. Precambrian Research 161, 419-451.

Verhoef, J., Macnab, R., Roest, W.R. \& Arjani-Hamed, J. 1996: Magnetic anomalies of the Arctic and North Atlantic oceans and adjacent land areas. Geological Survey of Canada, Open File Report 3125a, 225 pp.

\section{Author's address}

Geological survey of Denmark and Greenland, Øster Voldgade 10, DK-1350 Copenhagen K, Denmark. E-mail: prd@geus.dk 